\title{
Heroic Figures' Characters in Wayang Wong Dance Drama: A Character Education for the Elementary School Students?
}

\author{
Farida Nuryantiningsih*, Sri Nani Hari Yanti \\ Fakultas Ilmu Budaya, Universitas Jenderal Soedirman, Indonesia \\ faridanuryanti79@gmail.com*,srinani_7777@yahoo.co.id
}

DOI: 10.20884/1.j1i.2021.12.1.3432

\begin{abstract}
Article History:
First Received:

ABSTRACT

$26 / 10 / 2020$

Final Revision:

$19 / 06 / 2021$

Available online:

Wayang Wong is one Javanese traditional dance drama combining drama arts and wayang performance. The stories in Wayang wong performances are taken from Mahabarata and Ramayana. Many stories presented through wayang wong performances give various life examples through each figure's characters. Of those contained in wayang wong performances, this article only selected the figures from Mahabarata story as not only well known by the society like Gatotkaca, Arjuna, Bima/Werkudara, or Kresna, but also many Mahabarata story figures have good characters appropriate to become the examples for the character education at schools. Love, forgiveness, patience. responsibility, helpfulness, and other good characters belong to the Mahabarata story protagonist figures. This descriptive qualitative research used a cultural approach by identifying wayang wong figures' characters in both Ramayana and Mahabharata stories. The research data were collected using literature reviews on various relevant references to wayang wong to dig and obtain the descriptions of the wayang wong figures' characters in both Mahabharata and Ramayana stories as the character education for elementary school students. This article is greatly interesting because by introducing the protagonist figures through wayang wong performances, the children from Javanese ethnicity are expected to have good characters sourced from the local cultures. This is important because by knowing wayang figures, children are taught to love and conserve their nation's cultures.
\end{abstract}

Keywords: heroic figures; wayang wong; character education

\section{INTRODUCTION}

Wayang wong is a traditional art possibly enjoyed by all community levels. wayang wong traditional arts also contain various noble values. The values taught in wayang wong performances include human life teachings, the relationship between humans and nature as well as between God and humans. Wayang wong is a genre of traditional dance drama and the personification of wayang kulit purwa which stories are taken from Ramayana and Mahabharata epics. Wayang wong appeared in Surakarta Mangkunegaran Palace and Yogyakarta Kasultanan Palace in the middle of 
$18^{\text {th }}$ century (Supendi, 2007). Wayang wong is one traditional palace theatre developed by the Mataram kingdom (now Surakarta and Yogyakarta area). In wayang wong performance, there is a combination of literary art (role/theatre), musical art, painting art, and semiotics (Wardani \& Widiyastuti, 2013). Wayang wong performance can be used as information, education, entertainment, and other media to understand the philosophical values of Javanese culture that wayang wong has the power as a show and guidance. Wayang wong is the personification form of wayang purwa since the story structure, character selection, and language used in wayang wong are similar to those in wayang purwa. In wayang wong, the actors or actresses use dance and song as the dialog between figures. Thus, actors and actresses in wayang wong performance should be able to dance and sing.

Rustopo (2007) mentioned that the history of wayang wong in Surakarta started from the Keraton of Kadipaten Mangkunegara, which was at that time, under the government of Prince Adipati Mangkunegara I (1757-1796). Wayang wong was born when the Javanese literature experienced the renaissance period in the XVIII-XIX century marked by the kakawin (Ancient Java) writing in the new Javanese literary language. Meanwhile, Supadma (2015) mentioned that wayang wong first appeared in Ngayogyakarta Palace at the time of Hamengku Buwono I in 1757 which was then developed by the next Sultans. Wayang wong was initially performed for the important state ritual ceremony only. However, since 1918, the founder of Kridha Beksa Wirama (KBW), G. P. H Tejakusuma and P Soerjodiningrat, who was the son of Sultan Hamengku Buwana VII, successfully brought the dance out of the palace and was positively welcomed by the society with the Sultan's permission. Since then, wayang wong successfully passed through the palace and got positive responses from the common people level.

As one adiluhung artwork, wayang wong has an important role in the Javanese culture as the Javanese identity. Wayang wong art performance has two styles (in Javanese known as gagrak) consisting of gagrak Surakarta and gagrak Yogyakarta showing the wealth of Javanese people's culture although that two gagrak were born as the result of the colonial's political strategy of divide et impera to divide and conquer the sole entity of Mataram Sultanate. Each gagrak has its history, development story, and dynamics starting from behind the palace walls until its development outside the palace.

In Yogyakarta, wayang wong was first created by Sultan Hamengkubuwono I with the Gandawerdaya play, while in Surakarta, Mangkunegara I had the Wijanarka play. The Gandawerdaya play contains the patriotism spirit taken from the epic of Mahabharata particularly expressing the patriotism of the brave Pandawa knights in defending the truth and fighting against 
the crafty Kurawa (Bimo, 2014). The patriotism spirit in wayang wong was presented by Sultan Hamengkubuwono I remembering the time when the Sultan was facing the Dutch forces. Wayang wong in Yogyakarta Sultanate is a very modest group dance as not focusing on the sparkling costumes and other instruments, but creating a strong spirit and appreciation of the figures' characters. Thus, Yogyakarta's classical dancing style including wayang wong shows a more classical characteristic than Surakarta's which has a more romantic sense. By maintaining its classical characteristics, Yogyakarta's dancing style is known as joged mataram. Meanwhile, Surakarta's dancing style is known as yasa enggal or creating the new one. Besides costumes, the difference between Yogyakarta's and Surakarta's dancing style is related to their dialog intonations. The dialog intonations in Surakartan wayang wong are more realistic following the emotional levels and happening situations with various intonations, while those in Yogyakarta are more monotonous.

Although there is a style or gagrak difference in Yogyakartan and Surakartan wayang wong, the stories or plays presented from those two palaces are similarly based on the epic of Mahabharata and Ramayana. The stories presented in wayang wong performances are based on the epic of Mahabharata, such as the Kresna Duta wayang wong performance in Theater Neue Flora Hamburg, Germany on Monday, 2 September 2019 initiated by Paramarta Karya Budaya Foundation, Indonesian-German Experts and Scholars Association, and Bremen-Indonesia Diaspora, as well as the Indonesian Ambassador in Germany, or the Mahabandhana wayang wong performance in Jakarta Arts Building (known as GKJ) on Friday, 3 October 2014 involving no less than 150 traditional artists from Surakarta, Yogyakarta, Semarang, and Jakarta. It was also supported by the stage stars from the alumni of the Indonesian Arts Institute (ISI) of Surakarta and Yogyakarta involving the artists from Wayang Wong Sriwedari group from Surakarta. The central character in the Kresna Duta story is Kresna. The tale of Kresna Duta narrated Kresna who became the Pandawa's messenger to face Kurawa. Kresna figure appeared as a god-king (a king who has a god's characters) having wise, righteous, superior, fair, and protective characters. Meanwhile, the central character in Mahabandhana story is Suman or Sangkuni. Mahandhana is illustrated as a 'big rope' woven by Suman/Sangkuni to gain power in a big kingdom named Hastina/Hastinapura. The crafty smart characters nicely wrapped in sweet and tempting words followed with agile strategies made Pandu the ruler, the noble-hearted, Dewi Kunti, Gendara, her sibling, and Destarastra, inevitably caught in the trap to realize his ambition. Those two wayang wong performances at least showed that the traditional art like wayang wong should have a strategic position or cultural reposition representing itself as the cultural capital. Besides, 
introducing the wayang wong dance drama with its figures to the children is greatly important to introduce the local culture to the elementary school students and develop the character education values through the figures found in wayang wong. This is also considered as one effort to minimize the children's preference for the foreign superhero figures, such as Superman, Spiderman, Batman, and others seen on their televisions and Youtube channels.

\section{Character Education}

Character education is one effort to fulfill the mandate of Indonesian Five Basic Principles (known as Pancasila) and the Preamble of the 1945 Constitution driven by the recently developing nation's factual problems, such as nation's disorientation and disintegration threats, people's poor appreciation to Pancasila, shifting ethical values in both state and nation's life, decreasing awareness to the nation's cultural values, and weakening independence. Therefore, the government has included character education as one national development priority program implicitly asserted in the National Long-term Development Plan (known as RPJPN) of 2005-2025. Character education is positioned as the basis to realize the vision of national development "creating a society with noble character, morality, ethics, cultural knowledge, and civilization based on the philosophy of Indonesian Five Basic (Pancasila)". Character education aims at developing the values forming the nation's characters, namely Indonesian Five Basic Principles (Pancasila) including (1) developing the student's potentials to become kind-hearted persons with excellent mind and behaviors; (2) building the nation possessing the character of Pancasila; and (3) developing the citizens' potentials to have good attitudes and confidence, proud of the nation, and love their fellow human beings. Meanwhile, character education has the functions to develop: (1) the nation's multicultural life; (2) the nation's intelligent, noble-valued, and contributing civilization for the development of human life, basic potentials to have kind-hearted, positive-minded, and good behaviors; and (3) peace-loving, creative, and independent citizens to harmoniously live side by side with the other nations (Kemendiknas [Ministry of National Education], 2011). To strengthen the implementation of character education, there are 18 character education values sourced from religion, Indonesian five basic principles (Pancasila), culture, and national education purposes consisting of (1) Religious, (2) Honest, (3) Tolerant, (4) Discipline, (5) Hard-working, (6) Creative, (7) Independent, (8) Democratic, (9) Curious, (10) having the high Nationality Spirit, (11) Loving the Country, (12) Appreciating Achievement, (13) Friendly/Communicative, (14) Peace-Loving, (15) Fond of reading, (16) having Environmental Awareness, (17) having Social Awareness, (18) Responsible (Kemendiknas [Ministry of National Education], 2009). 
The nation's cultural and character problems have recently become people's high attention. The problems arising in the society, such as corruption, violence, mass fights, consumptive economic life, youth moral disorientation, and other problems have become hot topics in various mass media and seminars. One alternative solution to overcome or at least to lessen the cultural problems and the nation's characters is education. Education is considered as one preventive alternative to building a better nation's new generations. As the preventive alternative, education is expected to develop the quality of the young generation in various aspects to reduce and lessen the causes of various cultural problems and nation's characteristics. Education cannot be separated from the students' environments, especially the cultural environments because the students cannot live inseparably from their environments and behave based on their cultural principles. The education which is not based on cultural values will result in students whose culture is forcibly removed from its roots. Consequently, the younger generations will no longer recognize their cultures and become strangers in their cultural environments. Besides, the more worrying aspect is that if younger generations no longer love their own cultures, it will become a threat to the community's cultural sustainability as one of the nation's wealth. If the younger generations have become strangers to their own cultures, they will be very susceptible to the influence of outside cultures or even tend to accept them without having any valuing process. This happens as younger generations do not have norms and national culture values possibly used as the basis to do any valuing process. Therefore, character education rooted in cultures is greatly important to teach those young generations can recognize and then preserve their own cultures to further become their strong self-identity (Kemendiknas [Ministry of National Education], 2010).

\section{Puppetry and Wayang Wong}

Wayang is one most well-known Indonesian culture art among many other artworks. In wayang, there are acting, dancing, singing, musical, speech, literary, painting, sculptural, and symbolic arts. Wayang is media to enlighten da'wah, education, entertainment, philosophical understanding, and entertainment. Wayang is one typical art performance from Indonesia which always tells the values, norms, cultures, and traditions growing and developing in the local communities' life. Wayang contains the local wisdom which beneficially builds the characters depicted from the wayang figures' characters (Fadjrie, 2013). Good characters in the society which are taken from the local wisdom should be strongly built and deeply internalized in daily behaviors. Local wisdom values are not outdated values, but the everlasting ones to synergize with the universal and modern values. 
Wayang is an epic that mainly tells about the heroism of its good figures' characters in facing and destroying the bad ones. Wayang which has passed many historical events from generation to generation has shown how its puppetry culture is strongly attached and becomes a part of Indonesia's life, especially in Java. This puppetry's long period of age shows how high is its values and meanings to the communities' life. This condition shows that puppetry stories can well develop based on the recent development era although there is a certain stereotyping element and shows its antiquity. However, the wayang stories were mostly passed down through the performance media, especially wayang kulit performances more than texts. The Wayang stories were first orally told from generation to generation and each teller created their ways to tell those stories. Wayang stories were told or communicated to society through performances, cassette tape records, or books. Wayang kulit performances, especially played by the famous puppeteers, were always full of audiences. Wayang lovers have never been bored watching wayang kulit performances although the stories and the puppeteers are the same, meaning that both have never been watched before. In each performance, there is always something new that is contextually different from the previous ones.

A wayang story is arranged based on a never-changing dramatic convention. Small changes happen only as variants, while the big ones beyond the sources have never happened (Amir in Nurgiyantoro, 1998:38). In terms of its benefits, wayang is a symbol or reflection of our daily life. Thus, watching a wayang performance is not different from watching ourselves in a mirror (Mulyono, 1989:15). Wayang wong is one wayang type in Indonesia. Wayang wong is a dance drama performed by human actors substituting the wayang puppets. Wayang wong is a dance genre categorized as a total theater that includes dancing, acting, literary, musical, fine, and sound arts (Supriyanto, 2013). In its performance, wayang wong does not only present an entertaining performance but also provides guidance containing moral values to be interpreted and practiced in our daily life. Wayang wong performance is a traditional art teaching concrete lessons and values through the concrete figures' characters as paragons. Wayang wong is considered a "living encyclopedia" by the Javanese people due to its completeness related to the lessons and values on the relationship between humans, nature, and God and how humans can reach their life perfection.

In wayang wong, performance, an actor acting one wayang figure should perfectly be able to show the figure's true characters. Empathy is greatly necessary to support the actor to well act the figure's characters and to well understand others. Empathy is considered as one effective way to recognize, understand, and evaluate others that someone can truly and deeply feel others' characters including the ways other people observe and face their problems and situations 
(Pamungkas, 2012). Wayang performance can be used as one learning media for children by implanting the esthetically-wrapped ethical values that wayang performance can be easily accepted by young generations, especially children.

\section{MATERIALS AND METHOD}

This descriptive qualitative research used a cultural approach by identifying wayang wong figures' characters in both Ramayana and Mahabharata stories. This research employed a study design since the researchers could only observe without controlling the events like having experimental research. The literature review was made to further identify the characters of wayang wong figures in both Mahabharata and Ramayana stories. The research data were collected using literature reviews on various relevant references to wayang wong to dig and obtain the descriptions of the wayang wong figures' characters in both Mahabharata and Ramayana stories as the character education for elementary school students.

The collected data were then processed through data reduction, data display, and data conclusion. First, the data irrelevant to the problems were reduced that only the supporting data were used. Second, the selected data were then displayed to more clearly explain the collected data. Third, the data were further classified based on predetermined categories. Fourth, data were then concluded through depiction and verification.

\section{RESULTS \& DISCUSSION}

Character education which is based on the local culture has become one innovation in learning processes by providing more places for children to participate in transferring and conserving the local wisdom as a part of life values implanted in the society. The implementation of character education which is based on local cultures, such as the introduction of superhero figures' characters in wayang wong performances as one learning strategy, is expected to increase their recognition and sense of ownership on the local cultural heritage. The recognition and sense of ownership of the local culture heritage are greatly required as motivations and spirits in conserving the local cultures and maintaining the values of the existing local wisdom. These values will then become the spirits sustainably supporting the inheritance efforts of rasa (taste), cipta (idea/creativity), karsa (intention), and karya (work/creation) (Hapsari, 2019).

In each wayang performance, either wayang kulit or wayang wong, there is always colored with wayang figures with various characters: some with bad characters, while some others with 
good characters. Those with good characters are, for example, Pandawa in Mahabharata epic and Sri Rama in Ramayana epic. Meanwhile, those with bad characters included Kurawa in Mahabharata epic and Rahwana in Ramayana epic. In the cultural context, the figures' characters in wayang wong as an artwork performance can be used as character education media for elementary school students. Wayang wong performance with the story or sanggit played by the figures was based on the Javanese local culture containing the esthetically wrapped ethical values. By introducing the figures in wayang wong performance to children, it is expected that they recognize, understand, and are familiar with the wayang figures in their local culture. Besides, by introducing the figures in wayang wong based on the local culture to children, it is expected that they can catch and take the local wisdom values contained in the wayang wong performance as valuable messages.

Fadjrie (2013) stated that recently not many children know wayang wong. Many children even do not know the wayang figures, moreover the stories. This opinion is strengthened with the research conducted by Isnaeni (2018) stating that most early-age children did not know the wayang figures in Indonesia. Isnaeni tried to give some pictures of wayang figures to them and in fact, those children did not know and recognize those shown wayang figures. On the contrary, when Isnaeni showed foreign superhero figures (such as batman, superman, and spiderman), the children immediately recognized their names and powers.

The phenomena of western superhero movies with their characters always draw the viewers' attention and become the children's idols. The world's great enthusiasm for superhero movies increasingly sparks competitions among creative industries on famous superheroes. The superhero figures frequently appear with the stereotype of half-god ability or obtaining powers from the natural elements. Those characters are presented and destined to save the world and maintain the peace of the world. Unfortunately, these world savior figures idolized by the children do not come from Indonesia. In fact, for centuries, our ancestors have created the imaginative superhero figures existing in the Javanese wayang figures that also have the superhero abilities just like those foreign superhero figures. Stories (plays) in wayang performance also provide stories with ideal hero figures gifted with strengths and abilities beyond the limits of human powers, such as powerful weapons, flying ability, and giant form. Wayang figures should also be known, loved, and preserved by the Indonesian young generations since those wayang characters are based on the Indonesian local wisdom. Puppetry has been well implanted and has become a part of Indonesian people's life, especially in Java. In puppetry art, either in wayang kulit or wayang wong, there is a pearl of local wisdom which can be used to build the Indonesian character and identity depicted 
from the stories and the figures' characters. Character education which is based on the local wisdom as the identity of Indonesia for young generations is greatly important to create the children of the nation who are smart and have noble personalities and characters (Pandanwangi, 2018). Unfortunately, young generations do not love our own nation's wayang figures. Wayang figures should be well maintained as the cultural heritage which is full of character education values in the middle of the recent globalization and modernization.

In this article, wayang figures are introduced in wayang wong performances with various heroic figures. These heroic figures are considered important to be introduced to the elementary school students that they will also idolize the superhero figures coming from their own cultures teaching many local wisdom values as the children's character education. The introduction of superhero figures in wayang wong aiming at preserving and loving the local cultures. The wayang figures to introduce are those heroic characters in both Mahabharata and Ramayana stories, such as Bima/Werkudara, Arjuna, Gatotkaca, Kresna, and Rama. There are many wayang stories, but the dramatic conventions are the same and have never been changed. The dramatic conventions of wayang consist of the story structures, figures with certain character patterns, and language used, that is, Javanese language (Nurgiyantoro, 2011).

\section{Bima/Werkudara}

Bima or Werkudara was the second son of Dewi Kunti/Dewi Prita (the daughter of Prabu Basukunti, King of Mandura) and Prabu Pandudewanata (King of Astinapura). The other names of Werkudara were Bratasena, Bimasena, Haryasena, Bayusiwi, Jaga Abilawa, Kusumadilaga, Jayalaga, and Prabanconosiwi. Werkudara had three wives named Dewi Nogogini, Dewi Arimbi, and Dewi Urangayu. Raden Antareja was his son with Dewi Nagagini, Raden Gatutkaca was his son with Dewi Arimbi, and Raden Antasena was his son with Dewi Arangayu (Nugraha, 2014).

In the puppetry world, Bima is depicted as a figure with ideal heroic characteristics. Bima is the manifestation of a fighter with a big and tall, muscular, and athletic body. In Baratayudha epic, Bima was illustrated as a sadistic and brutal fighter when facing Kurawa. However, he was a loving person, especially to his family, and willing to sacrifice anything. In his fights, Bima had an unlimited physical power thanks to the sacred utterances of Bandungbandawasa. Bima had a powerful weapon called Gada Rujakpolo and Bargawa (big axe). Gada Rujakpolo is a Thor's mjolnir-like big axe. If mjolnir could release lightning power, Gada Rujakpolo would be bigger and heavier when crushing the enemies' weapons and became stronger. Bima also had very strong 
Pancanaka nails. These nails came from the ivory shards of Gajah Sena, an elephant-like figure of the reincarnation of Batara Bayu ripping the Bima's cuticle and helped him be born on earth.

\section{Arjuna}

Arjuna is a protagonist figure in Mahabharata story. Arjuna is greatly known as one of Pandawa members with a perfect physical appearance and gentle attitude. Arjuna is the third son of Dewi Kunti with Prabu Pandudewanata. Arjuna is a knight who loves wandering, meditating, and learning. Not only becoming the student of Hermit Drona in Sukalima hermitage, but he also became the student of hermit Padmanaba in Untrayana Hermitage. Arjuna had many names, such as Parta (war hero), Janaka (having many wives), Pemadi (handsome), Dananjaya, Kumbang aliali, Ciptaning Montaraga (holy priest), Pandusiwi, Indratanaya (son of Bathara Indra), Jahnawi (agile), Palguna, Danasmara (great charmer), and Margana (helpful). With his perfect physical performance, Arjuna was depicted as a man loved by many women that Arjuna was told to have 15 wives:

1. Dewi Sumbadra, had a son named Raden Abimanyu

2. Dewi Larasati, had two sons named Raden Sumitra and Bratalaras.

3. Dewi Srikandi

4. Dewi Ulupi/Palupi, had a son named Bambang Irawati

5. Dewi Jimambang, had two sons named Kumaladewa and Kumalasakti

6. Dewi Ratri, had a son named Bambang Wijanarka.

7. Dewi Dresnala, had a son named Raden Wisanggeni

8. Dewi Wilutama, had a son named Bambang Wilugangga.

9. Dewi Manuhara, had two sons named Endang Pregiwa and Endang Pregiwati

10. Dewi Supraba, had a son named Raden Prabakusuma

11. Dewi Antakawulan, had a son named Bambang Antakadewa.

12. Dewi Maeswara

13. Dewi Retno Kasimpar

14. Dewi Juwitaningrat, had a son named Bambang Sumbada.

\section{Dewi Dyah Sarimaya}

In the puppetry world, Arjuna is depicted as a figure with the characters of smart, clever, quiet, conscientious, polite, brave, and loving protecting the weak. He led Madukara Kadipaten located in the area of Amarta. After the Bharatayuda war, Arjuna became the King of Banakeling, formerly the Jayadrata kingdom. He was good at archery and had a heroic soul. Arjuna was also 
known as the best descendant of Kuru dynasty. He was the chosen one who got the chance to get the holy advice from Kresna, known as Bhagawadgita (God's songs). Besides, Arjuna was an undefeatable fighter when fighting on the battlefield although he was a slim and kind-hearted person he had a very strong will that in Baratayuda war he was able to force himself to kill his stepbrother, Karna.

Arjuna was once a Pandita in Mintaraga Cave, entitled Bagawan Ciptaning. He was destined to kill Prabu Niwatakawaca, the giant king of Manimantaka. For his merit, Arjuna was crowned as the King of Kahyangan Kaindran entitled Prabu Karitin and blessed with the sacred heirlooms from gods, such as Gendewa (from Bathara Indra), Ardadadali Arrow (from Bathara Kuwera), and Cundamanik Arrow (from Bathara Narada). Arjuna also had other sacred heirlooms, such as Keris Kyai Kalanadah, Sangkali Arrow (from Hermit Durna), Candranila Arrow, Sirsha Arrow, Keris Kyai Sarotama, Keris Kyai Baruna, Keris Pulanggeni, Terompet Dewanata, a box filled with Jayengkaton oil (from Bagawan Wilawuk from Pringcendani hermitage) and Ciptawilaha horse with Kyai Pamuk whip. Arjuna also had sacred utterances which made him become more powerful such as Panglimunan, Tunggengmaya, Sepiangin, Mayabumi, Pengasih and Asmaragama (Astuti, 2014). Arjuna also had some clothes symbolizing greatness, such as Limarsawo cloth, Limarkatanggi belt, Minangkara bun, Candrakanta necklace, and Mustika Ampal ring (previously owned by Prabu Ekalaya, King of Paranggelung). At the end of his life, Arjuna was told that he died in muksa (perfect death) with his other four siblings.

\section{Gatotkaca}

Gatotkaca is one greatly famous wayang figure. Gatotkaca was the son of Bima and Arimbi (a princess from Pringgadani, a giant kingdom). When he was a baby, he was named Tutuka. In his tale, no tools or weapons could cut the baby Tutuka's umbilical cord. Seeing the situation, Arjuna, the uncle, immediately went meditating to get a clue to help his nephew. Arjuna was then blessed with Konta Wijaya heirloom from Batara Narada to cut the baby Tutuka's umbilical cord. Konta Wijaya heirloom was able to cut the baby Tutuka's umbilical cord. One extraordinary event then happened as Konta Wijaya united itself with the baby Tutuka's body and added the baby Tutuka's power. Baby Tutuka was raised by Batara Narada. Batara Narada threw the baby Tutuka to Candradimuka crater of Mount Jamurdipa. At the same time, the gods threw various sacred heirlooms to the crater and after some time, the baby Tutuka jumped out of the crater as an adult man with various sacred heirlooms merged and united with his body and made him more powerful. At that time, Batara Guru, the ruler of the heaven gave a set of sacred heirloom clothes, such as 
Caping Basunanda, Kotang Antrakusuma, and Teropah Padakacarma. With those heirloom clothes, Tutuka could fly at a high speed to the Trabelasuket kingdom and killed the king of Kalapracona. Since then, Tutuka's name was changed into Gatotkaca (elib.unikom.ac.id).

In the puppetry world, Gatotkaca was told to have amazing power. In Kurukshetra great war, he killed many of Kurawa's allies before finally died in Karna's hands. In Indonesia, Gatotkaca becomes a very popular wayang figure. His power was told greatly amazing, such as flying without wings, and well known with the title of "otot kawat tulang besi/having wire muscles and iron bone". Gatotkaca was told to have brave, determined, tough, clever, fast, agile, steadfast, and greatly responsible characters. He was greatly powerful and had the Narantaka sacred utterances given by Hermit Seta. Gatotkaca was also known as Arimbiatmaja, Bimasiwi, Guritna, Gurudaya, Kacanegara (loving his own kingdom), Purbaya, Kancing Jaya (key of victory).

\section{Kresna}

Kresna was the son of Prabu Basudewa (King of Mandura) and Dewi Mahendra/Maekah. At a younger age, Kresna was named Narayana. Kresna had a twin sibling named Kakrasana, and a younger sister named Dewi Sumbadra, while Dewi Lara Ireng was the daughter of Prabu Basudewa and Dewi Badrahini. Kresna is the last reincarnation of the God, Sanghyang Wisnu. Besides known power, Kresna also had many sacred heirlooms, such as Wijayakusuma flowerlike disk weapon, Pancajahnya valve-less trumpet, Paesan Mirror, as well as Pameling and Kawrastawan sacred utterances. Kresna had several names, such as Cakradhara (disk-like weapon holder), Cangkhacakrasipani (clam snail and disk-like weapon holder), and Padmanaba sword (possessing a lotus in his navel), Devakiputra (son of Devaki), Gopala/Govinda (cow shepherd), Garudadhvaja (Garuda-flagged), Janardana (adored by mankind), Trilokyanatha (the ruler of three worlds), Vasudeva (son of Vasudeva) (Sundari, 2015). Prabu Kresna had 4 (four) empresses consisting of Dewi Jembarwati who had children named Samba and Gunadewa (appearing as monkeys); Dewi Rukmini who had the child named Saradewa (appearing as a giant), Partadewa, and Dewi Titisari/Sitisari; Dewi Setyaboma, who had the child named Arya Setyaka; Dewi Pratiwi who had the children named Bambang Sitija and Dewi Siti Sundari.

In the puppetry world, Kresna was told to have the peace-loving characteristics shown when Baratayuda war was going to happen. Kresna requested the dispute peacefully settled by dividing the kingdom; defender of justice, virtuous as proven through Kresna's loyalty to his words given to Drupadi saying that all Kurawa members who had humiliated by stripping Drupadi's clothes would die on the battlefield. Kresna swore in front of Drupadi that Kresna was born in this 
world to protect truth and uphold the Dharma laws to exterminate the evilness appearing throughout the centuries. However, Kresna also had some weaknesses in abducting Rukmini who should have been married to King Cedi.

\section{Rama}

In Ramayana epic, Rama was the main figure. As the main figure, Rama has become the symbol of Hinduism teaching and philosophy. Rama/Sri Rama was the eldest son of King Dasarata and Queen Kosalya, the descendant of Surya or Suryawangsa Dynasty. Rama came from Kosala Kingdom with the capital city of Ayodhya. Ayodhya was a fertile and wide country led by King Dasarata. Dasarata was known as a fair and wise King in leading the citizens to live in peace and safety. Rama had many names, such as Ramayana, Ramaragawa, Ramacandra, Ramabadra, Ramadewa, and Raguputra. Rama also had four step siblings named Laksmana from Dewi Sumitra, Barata, Satrugna, and Dewi Kawakwa from Dewi Kekayi. Rama had Dewi Shinta as her wife after winning an interesting Heirloom Arc contest held in Mantili Kingdom (Mithiladiraja). Rama had some children named Kusiya and Rama Batlawa.

According to Hindu belief, Rama was the reincarnation of the seventh God, Wisnu who descended on earth. Rama was seen as Maryada Purushottama, meaning the "Perfect Human". In his childhood and adolescence, he was educated with virtues and powers by Bhagavan Waistha. Because of his intelligence, powers, and virtuous attitudes, Sri Rama was endowed with the incarnation of Sang Hyang Wisnu who had to destroy the evilness on earth. Rama Wijaya was a great knight at wars. He had gentle attitudes and greatly talented in using weapons, especially arrows. He was highly diligent in practicing archery that no knights were able to match him. No matter how big the arc was, he was always able to bend it, and no matter how far the target was, he could always hit it right on target.

\section{CONCLUSION}

Local wisdom, especially wayang, is the energy collectively belonging to the Javanese people to become a more civilized society. The local wisdom taught and passed down to younger generations can be used as the character education to prevent various problems in the middle of modernization. By inheriting the local culture and practicing the local wisdom values, the youth is expected to be able to politely answer the future challenges based on their own cultures. Besides, the local wisdom values possibly become the bridge between the local cultures and global currents. 


\section{ACKNOWLEDGEMENT} 2020.

This research was funded by LPPM Universitas Jenderal Soedirman with Riset Institusional

\section{REFERENCES}

Fajrie, N. (2013). Media Pertunjukan Wayang Untuk Menumbuhkan Karakter Anak Bangsa dalam Prosiding Pendidikan Profesi dan Karakter Bangsa dalam Pembelajaran Bahasa dan Sastra https://publikasiilmiah.ums.ac.id/xmlui/handle/11617/3486.

Hapsari, I. (2019). Pertunjukan Wayang Wong sebagai Media Pembelajaran Berbasis Budaya Lokal dalam Prosiding Seminar Internasional Riksa Bahasa XIII, Bandung: 23 November 2019. Hal. 1283-1288.

Noor, I. F. (2018). Edi Surojo Media Pengenalan Kebudayaan Lokal Berbasis Karakter Untuk Anak Usia Dini. Jurnal Pendidikan Anak, 7 (1).

Bimo, K. A. (2014). Perbedaan Wayang Orang Gaya Surakarta dan Gaya Yogyakarta diunduh dari http://infobimo.blogspot.com/2014/01/perbedaan-wayang-orang-gaya-surakarta.html 30 Mei 2020.

Kementerian Pendidikan Nasional. (2009). Pengembangan dan Pendidikan Budaya dan Karakter Bangsa: Pedoman Sekolah. Jakarta: Pusat Kurikulum.

Kementerian Pendidikan Nasional. (2010). Bahan Pelatihan Penguatan Metodologi pembelajaran Berdasarkan Nilai-Nilai Budaya untuk Membentuk Daya Saing dan Karakter bangsa. Jakarta: Badan penelitian dan Pengembangan Pusat Kurikulum dan perbukuan.

Kementerian Pendidikan Nasional. (2011). Panduan Pelaksaan Pendidikan Karakter. Jakarta:

Badan penelitian dan Pengembangan Pusat Kurikulum dan perbukuan.

Lickona, T. (1991). Educating for Character: How Our School Can Teach Respect and Responsibility. New York. Auckland: Bantam Books.

Nurgiyantoro, B. (2011). Wayang dan Pengembangan Karakter. Jurnal Pendidikan Karakter, 1 (1).

Ikram, N. M., Sumarno, S. H. (2014). Implementasi Nilai Karakter Tokoh Werkudara Dalam Pembelajaran Sejarah diunduh dari https://repository.unej.ac.id/handle/123456789/63457 diunduh 4 Mei 2020.

Pamungkas, E. A. (2012). Proses Empati pada Pemeranan Tokoh Wayang oleh pemain Wayang Wong di Sriwedari diunduh dari http://eprints.ums.ac.id/18342/ diunduh 16 Juni 2020.

Rustopo. (2007). Menjadi Jawa: Orang-Orang Tionghoa dan Kebudayaan Jawa. Yogyakarta: Ombak.

Ryan, K., Bohlin, K. E. (1999). Building Character in Schools: Practical Ways to Bring Moral Instruction to Life. San Fransisco: Jossey-Bass A Wiley Imprint.

Astuti, S. R. (2014). Arjuna: Ksatria Lemah Lembut Tetapi Tegas. Jantra , 9 (2). 
Supadma. (2015). Teliti Wayang Wong Kraton, Dosen ISI Yogyakarta Raih Doktor diunduh dari https://ugm.ac.id/id/berita/9674-teliti-wayang-wong-kraton-dosen-isi-yogyakarta-raih-doktor 30 Mei 2020.

Supendi, E. (2007). Wayang Orang sebagai Pertunjukan Teater Tradisional dalam Tinjauan Semiotika sebuah Kajian Awal. Jurnal Gelar, 5 (1): 54-72.

Wardani, N. Eko., Widiyastuti, E. (2013). Mapping Wayang Traditional Theatre as A Form of Local Wisdom of Surakarta Indonesia. Asian Journal of Social Science \& Humanities, 2 (2): 314321.

Pandanwangi, W. D., Nuryantiningsih, F. (2018). Komik Wayang Anak Pandawa Sebagai Media Pendidikan Karakter Di Jaman Kekinian" http://journal.isi.ac.id/index.php/JOUSA/article/view/2208 diunduh15 Mei 2020.

Sundari, A. 2015. Tokoh Kresna Dalam Wiracarita Mahabharata Sebagai Tokoh Identifikasi Etik Moral dalam Prosiding Seminar Nasional Dan Folklor Dan Kearifan Lokal Jurusan Sastra Indonesia-Fakultas Sastra Universitas Jember 212-264. https://repository.unej.ac.id/handle/123456789/77000 diunduh 5 Juni 2020.

Supriyanto. (2013). Wayang Wong sebagai Pusaka Keraton Yogyakarta. Jurnal Greget, 12 (1). 